Original Article

\title{
EFFECTIVENESS OF AN INFORM ATION BOOKLET ON KNOWLEDGE AM ONG STAFF NURSES REGARDING PREVENTION AND MANAGEMENT OF PERINEAL TEAR DURING NORMAL DELIVERY
}

\author{
Philomena Fernandes ${ }^{1}$, Shiney Paul ${ }^{2} \&$ Savitha B. $^{3}$ \\ ${ }^{1}$ Assoc. Professor \& H.O.D, ${ }^{2}$ Professor \& P.G Co-ordinator, ${ }^{3}$ Asst. Lecturer \\ Department of Obstetrics \& Gynaecological Nursing, \\ Correspondence: \\ Philomena Fernandes \\ Mobile : 9194492 07845. E-mail : philferns7@gmail.com
}

Nitte Usha Institute of Nursing Sciences, Nitte University, Deralakatte, M angalore - 575018

\begin{abstract}
:
The study was conducted to evaluate the effectiveness of an information booklet on knowledge among staff nurses regarding the prevention and management of perineal tear during normal delivery. An evaluative approach with one group Pre test Post test design was used for the study. 40 samples were selected using simple random sampling method. The present study was conducted in Justice K.S. Hegde Charitable hospital Mangalore. The collected data were analysed using descriptive and inferential statistics. A significant difference between Pre test and Post test knowledge was found $(t=23.09, p<0.05)$. The study findings showed that the information booklet was effective in improving knowledge of staff nurses regarding prevention and management of perineal tear during labour. There was no significant association between the level of knowledge and demographic variables.
\end{abstract}

Keywords: knowledge, perineal tear, information booklet.

\section{Introduction:}

An unwelcome consequences of vaginal birth is perineal tearing and episiotomies. Perineal injuries can lead to pain, bleeding, scarring dyspareunia, infection, urinary or fecal incontinence and interference with establishment of breast feeding.The Royal college of Obstetricians and gynecologist estimates that $85 \%$ of women who have vaginal delivery will have some degree of perineal tear and that 60 - 70\% will require suturing.

The medical literature is clear in recommending minimal perineal trauma during child birth. The intrapartum nurses can put a great value on advocate the labouring women to practice the perineal care techniques used to decrease the

Access this article online Quick Response Code

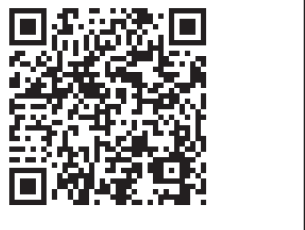
perineal trauma.Tears are more common in women having their first vaginal birth and ranges from small nicks and abrasions to deep lacerations affecting several pelvic floor muscles. Some maternal tissues tear more easily than others. Very large infants or unusual fetal positions are a special threat to the perineum.At least $4 \%$ of women who deliver vaginally end up with a more serious tear in their perineum. Sometimes this happens when an episiotomy is done and the tissue then tears further on its own.

In 2002, Weber and Meyn from Pittsburgh reviewed the National Hospital Discharge survey database from 1979 to 1997 and revealed that the Anal sphincter laceration occurred in $8.3 \%$ of women without an episiotomy and $3.8 \%$ with an episiotomy. ${ }^{3}$

Perineal, vaginal or cervical lacerations are often result of trauma to maternal tissue during delivery. Nurse mid-wives play a significant role in health promotion and health prevention, and there are variety of techniques which can be adopted by them to impart knowledge to the health care professionals. Hence the investigators felt to take up this study in order to equip the staff nurses with knowledge on prevention and management of perineal tear while conducting delivery. 


\section{Materials and Methods :}

In order to accomplish the main objective of evaluating the effectiveness of an information booklet on knowledge among staff nurses regarding prevention and management of perineal tear during normal delivery, one group Pre test Post test design which is a pre experimental design was adopted. The study was conducted in Justice K.S. Hegde Charitable hospital Mangalore. Simple random sampling technique was used for selection of 40 staff nurses. Pretest was administered to the participants using structured knowledge questionnaire. After pretest researcher distributed information booklet on prevention and management of perineal tear to the participants. After 7 days of intervention the investigator administered the post test to assess the level of knowledge of staff nurses using the same structured knowledge questionnaire.The collected data were analysed using descriptive and inferential statistics.

\section{Results:}

M ain findings are discussed under the following headings

\section{SECTION 1:}

\section{DESCRIPTION OF SAM PLE CHARACTERISTICS}

Distribution of staff nurses according to the demographic characteristics

G $60 \%$ of staff nurses were in the age group of 1825 years, $32.5 \%$ were in the age group of 26-33years, $5 \%$ were between $34-41$ years and $2.5 \%$ were in the age group of 41-49 years.

G 85\% were Diploma nurses, 15\% were B.Sc /P.B.B.Sc Nursing.

G 35\% were having an experience of more than 4 years, $22.5 \%$ were experience between $3-4 y e a r s, 20 \%$ of staff nurses had less than lyear of experience, $17.5 \%$ were having experience between 1-2years and only $5 \%$ of staff nurses had the experience of 2-3years

G $52.5 \%$ of the staff nurses availed information from inservice education, $40 \%$ from CNE/Workshop, $5 \%$ from Mass Media and only $2.5 \%$ of the staff nurse received information from Distance education.
G 70\% of the staff nurses were not having experience in the labour room, $27.5 \%$ of the staff nurses were having $<1$ year experience in labour room, $2.5 \%$ of the staff nurse have between 1-2 years of experience in labour room.

\section{SECTION II:}

KNOWLEDGE OF STAFF NURSES ON PREVENTION AND MANAGEMENT OF PERINEAL TEAR DURING NORMAL DELIVERY:

Distribution of pre-test and post-test knowledge scores of staff nurses regarding prevention and management of perineal tear during normal delivery.

$n=40$

\begin{tabular}{|l|c|c|c|c|}
\hline SCORE & \multicolumn{2}{|c|}{ PRE-TEST } & \multicolumn{2}{c|}{ POST-TEST } \\
\hline RANGE & FREQUENCY & PERCENTAGE & FREQUENCY & PERCENTAGE \\
\hline POOR & & & & \\
\hline$(0-14)$ & 15 & $37.5 \%$ & 0 & 0 \\
\hline AVERAGE & & & & \\
\hline$(15-22)$ & 24 & $60 \%$ & 0 & 0 \\
\hline GOOD & & & & \\
\hline$(23-30)$ & 1 & $2.5 \%$ & 23 & $57.5 \%$ \\
\hline VERY & & & & \\
\hline GOOD & & & & \\
\hline$(31-38)$ & 0 & 0 & 17 & $42.5 \%$ \\
\hline
\end{tabular}

The data presented in the table displays the frequency distribution of staff nurses according to their pretest knowledge scores. The data showed that $60 \%$ had average knowledge, $37.5 \%$ had poor knowledge, and only $2.5 \%$ had good knowledge.

The data presented in the table shows the frequency distribution of staff nurses according to their post test knowledge scores. The data showed that $57.5 \%$ had good knowledge and $42.5 \%$ had very good knowledge. 
Area wise percentage of pre-test and post test knowledge scores and gain scores of staff nurses $(n=40)$

\begin{tabular}{|c|c|c|c|c|c|}
\hline \multirow[t]{2}{*}{ SI. No } & \multirow[t]{2}{*}{ Areas } & \multicolumn{2}{|c|}{ Mean percentage } & \multicolumn{2}{|c|}{ Gain scores } \\
\hline & & Pre-test & Post-test & Actual & $\begin{array}{l}\text { Modified } \\
\text { gain }\end{array}$ \\
\hline 1. & $\begin{array}{l}\text { Meaning of } \\
\text { perineum and } \\
\text { related factors }\end{array}$ & 28.33 & 61.25 & 32.92 & 0.459 \\
\hline 2. & $\begin{array}{l}\text { Causes of } \\
\text { perineal tear }\end{array}$ & 48.55 & 78.33 & 29.78 & 0.578 \\
\hline 3. & $\begin{array}{l}\text { prevention and } \\
\text { management of } \\
\text { perineal tear }\end{array}$ & & & & \\
\hline & $\begin{array}{l}\text { (a)timely } \\
\text { episiotomy }\end{array}$ & 41.69 & 75.19 & 33.5 & 0.574 \\
\hline & $\begin{array}{l}\text { (b)perineal } \\
\text { massage }\end{array}$ & 30 & 80.08 & 50.08 & 11.071 \\
\hline 4. & Knowledge on & & & & \\
\hline & perineal tear & & & & \\
\hline & repair & 45.5 & 87.5 & 42 & 0.770 \\
\hline
\end{tabular}

The data presented in table indicate that the post test mean percentage knowledge scores in all content areas were higher than the pre test mean percentage knowledge scores. The maximum post test mean percentage score was in the area of Knowledge on perineal tear repair. The data also shows that least modified gain was seen in the area of meaning of perineum and related factors (0.459) and the lowest pretest scores in area, Meaning of perineum and related factors (28.33), demonstrated the maximum modified gain in the area of prevention and management of perineal massage (11.071) which showed that information booklet on prevention and management of perineal tear during normal delivery was effective.

\section{SECTION III:}

\section{EFFECTIVENESSOF INFORM ATION BOOKLET}

Mean, Mean Difference, Standard error of Difference, and't' value of pre-test and post-test knowledge scores of staff nurses $(n=40)$

\begin{tabular}{|l|c|c|c|c|c|c|}
\hline & Mean & M ean & SD & Df & 't'value & P'value \\
\hline & & difference & & & (LOS) & \\
\hline Pre-test & 14.7 & 15.3 & 4.18 & 39 & 23.09 & 0.00 \\
\hline Post-test & 30.0 & & & & & P $<0.05 \mathrm{~S}$ \\
\hline
\end{tabular}

The data shows that the mean post-test knowledge scores of staff nurses were significantly higher than their mean pretest knowledge scores. The calculated't' value is 23.09 which is greater than the table value 2.02 $(p \varangle 0.05)$.Therefore the information booklet has been an effective method of increasing the knowledge of the staff nurses.

\section{Discussion :}

The effectiveness of an information booklet was supported by the findings in a study which was conducted in Bangalore (personal communication)* regarding effect of Pamphlet on knowledge among staff nurses regarding prevention and management of perineal tear while conducting normal delivery. The study revealed that the total mean percentage of pre test was $45.30 \%$ and the mean post test score was $80 \%$ showing an effectiveness of $34.7 \%$.Significance of difference between pre test and post test prevention and management was statistically tested using paired ' $\mathrm{t}$ ' test and it was found significant ( $t=22.512, p, 0.05$ and $t=20, p, 0.05$ respectively).

Area-wise mean difference, standard deviation and't' value of pretest and post test knowledge scores. $(n+40)$

\begin{tabular}{|c|c|c|c|c|c|c|c|c|}
\hline \multirow[b]{2}{*}{ SI.no } & \multirow[b]{2}{*}{ Areas } & \multicolumn{2}{|c|}{\begin{tabular}{|l|} 
Mean \\
knowledge \\
scores
\end{tabular}} & \multirow{2}{*}{\begin{tabular}{|c|} 
\\
$\begin{array}{c}\text { Mean } \\
\text { diff. }\end{array}$
\end{tabular}} & \multirow[b]{2}{*}{ df } & \multirow[b]{2}{*}{ SD } & \multirow[b]{2}{*}{\begin{tabular}{|c|} 
't' \\
value
\end{tabular}} & \multirow[b]{2}{*}{$\begin{array}{c}\mathbf{P} \\
\text { value }\end{array}$} \\
\hline & & \begin{tabular}{|l|} 
Pre \\
test \\
\end{tabular} & \begin{tabular}{|l|} 
Post- \\
test
\end{tabular} & & & & & \\
\hline 1 & $\begin{array}{l}\text { M eaning of } \\
\text { perineum and } \\
\text { related factors }\end{array}$ & 1.70 & 4.92 & 3.22 & 39 & 1.20 & 16.87 & $\begin{array}{c}0.000 \\
P<0.05 S\end{array}$ \\
\hline 2 & $\begin{array}{l}\text { Causes of } \\
\text { perineal tear }\end{array}$ & 3.92 & 7.05 & 3.12 & 39 & 1.82 & 10.81 & $\begin{array}{l}0.000 \\
P<0.055\end{array}$ \\
\hline \multirow[t]{3}{*}{3} & \multicolumn{8}{|c|}{ prevention \& management of perineal tear } \\
\hline & $\begin{array}{l}\text { a) Timely } \\
\text { episiotomy }\end{array}$ & 5.42 & 9.77 & 4.35 & 39 & 2.47 & 11.11 & $\begin{array}{l}0.000 \\
P \varangle 0.05 S\end{array}$ \\
\hline & $\begin{array}{l}\text { b) Perineal } \\
\text { massage }\end{array}$ & 1.80 & 4.85 & 3.05 & 39 & 1.44 & 13.31 & $\begin{array}{c}0.000 \\
P \varangle 0.05 S\end{array}$ \\
\hline \multirow[t]{2}{*}{4} & \multicolumn{8}{|c|}{ Knowledge on perineal tear repair } \\
\hline & & 1.82 & 3.40 & 1.57 & 39 & 1.48 & 6.71 & $\begin{array}{c}0.000 \\
P \varangle 0.05 S\end{array}$ \\
\hline
\end{tabular}




\section{SECTION IV:}

\section{ASSOCIATION BETWEEN PRETEST KNOWLEDGE SCORE AND SELECTED DEM OGRAPHIC DATA}

\begin{tabular}{|c|c|c|c|c|c|c|}
\hline Variables & $<$ median & $\geq$ median & $\chi^{2}$ value & $\chi_{\text {tab }}^{2}$ & df & LOS \\
\hline \multicolumn{7}{|c|}{ 1. Professional qualification } \\
\hline Diploma nursing & 14 & 20 & & & & 0.253 \\
\hline B.sc nursing & 1 & 5 & 1 & 0.471 & 3.841 & $p>0.05 \mathrm{NS}$ \\
\hline \multicolumn{7}{|c|}{ 2. Years of experience as a staff nurse } \\
\hline$<1$-3years & 4 & 13 & 2.839 & 5.59 & 2 & .242 \\
\hline 3-4years & 5 & 4 & & & & $p>0.05 \mathrm{NS}$ \\
\hline$>$ yyears & 6 & 8 & & & & \\
\hline \multicolumn{7}{|c|}{ 3. Source of information } \\
\hline CNE/workshop & 6 & 10 & 0.00 & 3.841 & 1 & 1.000 \\
\hline In-service/other & 9 & 15 & & & & $p>0.05 \mathrm{NS}$ \\
\hline
\end{tabular}

The above table results that there is no significant association between the proffesional qualification, year of experience as a staff nurse and source of information and knowledge level at 0.05 level of significance.

\section{Conclusions:}

Education is the key component in improving the knowledge of staff nurses, the nurses could be prepared in providing comprehensive nursing care and giving more emphasis on the management of normal labour .It could also include in the education which should help the staff nurses to identifyclients who are at risk for perineal tear and modify the care for preventing complications. Nurses needs to update their knowledge and practice based on research findings. Today nursing have grown up that nurses are challenged to play the role of efficient administrator as well as nurse practitioner. For this apart from knowledge of administration, nurses also must have good decision making and reasoning abilities. Updating knowledge regarding the recent innovations and evidence based practices help the nurse to implement the best needed and useful practices. The nurse administrator can play a key role in organizing and planning various programmes for staff nurses. The present study will also help the nurse administrator to utilize its findings while working in hospitals and community settings by making the health personnel well informed about various aspects of the perineal tear. All the staff nurses need to have knowledge about prevention of perineal tear and the related factors. There for a nurse as an administrator can also take initiative in parting the health information through different teaching methods. Nurse administrator can organize inservice education continuing education and workshop for nursing personnel.

\section{Acknowledgement:}

*Personal communication: Prathibha S.D (2008), 'To evaluate the effectiveness of Pamphlet on knowledge among staff nurses regarding prevention and management of perineal tear while conducting normal labour in selected Government maternity hospitals at Bangalore'. Dissertation submitted to Rajiv Gandhi University of Health Sciences

\section{References :}

1. Martin S, Labrecque $M, M$ arcoux $S$, et al. The association between perineal trauma and spontaneous perineal tears. J Fam Pract 2001; 50: 333-7.

2. Richter HE, Brumifield CG, Cliver SP, et al. Risk factors associated with anal sphincter tear: a comparison of primiparous patients, vaginal births after caesarian deliveries, and patients with previous vaginal deliveries. Am J Obstet Gynecol $\quad 2002 ; 187: 1194-8$

3. Weeks J D, Kozak CJ. Trends in the use of episiotomy in the United States: 1980-1998, Birth 2001; 28: 152-60.

4. Weber AM, M eyn L. Episiotomy use in the United States, 1979-1997. Obstet gynecol 2002; 100: 1177-82.

5. Howden NLS, Weber AM, M eyn LA. Episiotomy use among residents and faculty compared with private practitioners. Obstetr and gynecol 2004; 103: 114-8.

6. Shipman MK, Boniface DR, Tefft ME, et al. antenatal perineal massage and subsequent perineal outcomes; randomized controlled trial. $\mathrm{Br}$ J Obstet and gynecol 1997; 104:787-91.

7. Labrecque M, Eason E, M arcoux S, et al. Randomized controlled trial of 
prevention of perineal trauma by perineal massage during pregnancy. AmJ Obstet and gynecol 1999; 180:593-600.

8. Signorello LB, Harlow BL, Chekos AK, et al. Midline episiotomy and anal incontinence retrospectives cohort study. BMJ 2000; 320:86-90.

9. Williams A, Herron Marx, Carolyn H. The prevalence of enduring postnatal perineal morbidity and its relationship to perineal trauma. Midwifery [serial online] 2007 Dec [cited 2008 Nov 17]; 23940: 392403: Available from; URL: www.http// pubmed.com

10. Hastings TM, Vincent D, Emeis C, Francisco T. Getting through birth in one piece: Protecing the perineum. MCN Am J Matern Child Nurse [serial online] 2007 M ay [cited 2008 Nov 17]; 32(3): 158-64: Available from; URL: www.http// pubmed.com

11. Soong B, Barnes M. M aternal position at Midwife attended birth and perineal trauma: is there any association? [serial online]; 2005 Sep [cited 2008 Nov 17]; 32(3): 164-9: Available from: URL:www.http//pubmed.com

12. WHO, UNICEF, UNFPA, Maternal Mortality in 2000: Estimates Developed by WHO, UNICEF, UNFPA, GENEVA:WHO, 2004

13. Pilliteri A. Maternal and child health nursing. $4^{\text {th }}$ ed. Philadelphia: Lippincot Publication; 2004. p. 470, 518.

14. Kudish B, Blackwell S, M cneeley SG, Bujold E, Kruger M , Hendricks SLet al. Operative vaginal delivery and midline episiotomy: a bad combination for the perineum. Am J Obstet Gynecol [serial online]; 2006 Sep [cited 2008 Nov 18]; 195(3): 749-54: Available from: URL:www.http// pubmed.com

15. Dutta DC. Text book of obstetrics. $4^{\text {th }}$ ed. Calcutta: New Central Book Agency Private Limited; 1998. p. 11-2.

16. de Tayrae R, Panel L, M asson G, M ares P. Episiotomy and prevention of perineal and pelvic floor injuries. J Gynecol Obstet Biol Reprod [serial online] 2006 Feb [cited on Nov 17]; 35(1): Available from: URL: www. http//pubmed.com.

17. Lowdermilk LD, Perry ES, Bobak MI. Maternity nursing. $5^{\text {th }}$ ed. Philadelphia: Lippincott Publication; 1995. p. 394-5.

18. Dahlen HG, Ryan M, Homes CS, Cooke M . An Australian cohort study of risk factors of severe perineal trauma during child birth. Midwifery [serial online] 2007 June [cited 2008 Nov 18]; 23(2): 196-203: Available from; URL: www.http// pubmed.com
19. Reeder, Martin, Konaik G. Maternity nursing. $18^{\text {th }}$ ed. Philadelphia: Lippincot Publication; 1997. p. 566-7.

20. Sheiner E, Walfisch A, Hallak M, Harlev S, M azore M, et al. Length of second stage of labor as a predictor of perineal outcome after vaginal delivery. J Reprod Med [serial online] 2006 Feb [cited on Nov 17]; 51(2): Available from; URL: www.http// pubmed.com

21. Albers LL, Selder KD, Bedrick EJ, Teaf D, Peralta P. Factors related to genital tract trauma in normal spontaneous vaginal birth. [serial online] 2006 Jun [cited 2008 Nov 17]; 33(2): 94-100: Available from; URL: www.http//pubmed.com

22. M acarther AJ, M acarther C. Incidence, severity and determinants of perineal pain after vaginal delivery. AM J Obstet Gynecol [serial online] 2004 Oct [cited 2008 Nov 17]; 191-204: Available from; URL:www.http// pubmed.com

23. Albers LL, Selder KD, Bedrick EJ, Teaf D, Peralta P. Midwifery care measures in the second stage of labor and reduction of genital tract trauma at birth: a randamised trial. M idwifery Womens Health [serial online]; 2005 Sep [cited 2008 Nov17]; 50(3): 158-64: Available from; URL:www.http// Pubmed.com

24. Polit DF, Hungler BD. Nursing Research: Principles and methods, $6^{\text {th }}$ ed. Philadelphia: Lippincott, 1999.

25. Burns N. The practice of nursing research, Philadelphia, WB Saunders Company; 1998.

26. Talbot AL. Principles and practice of nursing research. St Louis: M osby Publishers; 1999.

27. Kothari CR. Research Methodology. New Delhi: Wishwa Prakashan; 2003

28. Polit DF, Beek CT, Nursing Research; Principles $\&$ methods, $7^{\text {th }}$ ed. Philadelphia, J.B Lippincott Company, 2000.

29. Basavanthappa BT. Nursing research. $1^{\text {st }}$ ed. New Delhi Jaypee 1998.

30. Nancy Burns, Susan K Grove, Understanding Nursing Research. $4^{\text {th }}$ edition. Elsevier Publication; 127-29.

31. Treece J, Treece E. Elements of Research in Nursing. $3^{\text {rd }}$ edition. St.Louis: M osby; 1982.

32. Evaluation of nurse midwives knowledge regarding perineal laceration during normal vaginal delivery. M other-Child and Psychiatric Nursing Department,Brazil 2007.Available from URL:http://scielo.br. 